\title{
Nucleotide Sequence of the Neopullulanase Gene from Bacillus stearothermophilus
}

\author{
By TAKASHI KURIKI AND TADAYUKI IMANAKA* \\ Department of Fermentation Technology, Faculty of Engineering, Osaka University, Yamadaoka, \\ Suita-shi, Osaka 565, Japan
}

(Received 15 December 1988; revised 1 March 1989; accepted 20 March 1989)

The gene (nplT) for a new type of pullulan-hydrolysing enzyme, neopullulanase, from Bacillus stearothermophilus TRS40 was sequenced. The DNA sequence revealed only one large open reading frame, composed of 1764 bases and 588 amino acid residues $\left(M_{\mathrm{r}} 69144\right)$. Although the thermostable neopullulanase contained eight cysteine residues, they did not provide conformational stability by disulphide bonds. A comparison was made of the amino acid sequences of $\alpha$-amylase, neopullulanase, isoamylase, pullulanase and cyclodextrin glucanotransferase. All the enzymes examined contained four highly conserved regions which probably constitute the active centres of the enzymes. The amino acid residues required for the specificity of neopullulanase are compared with those of $\alpha$-amylase and other amylolytic enzymes.

\section{INTRODUCTION}

Four types of pullulan-hydrolysing enzymes have been described (Imanaka \& Kuriki, 1989): (i) glucoamylase (glucan 1,4- $\alpha$-glucosidase; EC 3.2.1.3), which hydrolyses pullulan from nonreducing ends to produce glucose; (ii) pullulanase ( $\alpha$-dextrin endo-1,6- $\alpha$-glucosidase; EC 3.2.1.41), which hydrolyses $\alpha$ - $(1 \rightarrow 6)$-glucosidic linkages of pullulan to produce maltotriose; (iii) isopullulanase (EC 3.2.1.57), which hydrolyses $\alpha$-(1 $1 \rightarrow 4)$-glucosidic linkages of pullulan to produce isopanose (6-O- $\alpha$-maltosylglucose); and (iv) neopullulanase, which hydrolyses $\alpha-(1 \rightarrow 4)$ glucosidic linkages of pullulan to produce panose $\left(6^{2}-O-\alpha\right.$-glucosylmaltose). The last enzyme was reported to be a new type of pullulan-hydrolysing enzyme from Bacillus stearothermophilus TRS40 (Kuriki et al., 1988a). We have cloned the genes for the neopullulanase and pullulanase in Bacillus subtilis (Kuriki et al., 1988a, b, respectively). The neopullulanase could hydrolyse pullulan efficiently and only hydrolysed a small amount of starch. Further studies revealed that neopullulanase hydrolysed not only $\alpha-(1 \rightarrow 4)$-glucosidic linkages but also specific $\alpha-(1 \rightarrow 6)$ glucosidic linkages of several branched oligosaccharides (Imanaka \& Kuriki, 1989).

It was previously demonstrated that four highly conserved regions existed in eleven different $\alpha$-amylases (EC 3.2.1.1) (Nakajima et al., 1986) and the regions were most likely to be the active and/or substrate-binding sites of the enzymes (Matsuura et al., 1984). These homologous regions have also been discussed for other kinds of amylolytic enzymes (Amemura et al., 1988; Binder et al., 1986; Kimura et al., 1987; McPherson \& Charalambous, 1988; Sakai et al., 1987).

This paper describes the nucleotide sequence of the cloned neopullulanase gene. To further investigate the unique action pattern of the neopullulanase at the molecular level, the amino acid sequence of the neopullulanase is compared with those of $\alpha$-amylase, isoamylase, pullulanase and cyclodextrin glucanotransferase, and the specificity of the neopullulanase is described.

\section{METHODS}

Bacterial strains, plasmids and phages. The Bacillus strain used was Bacillus subtilis NA-1 (arg-15 hsmM hsrM

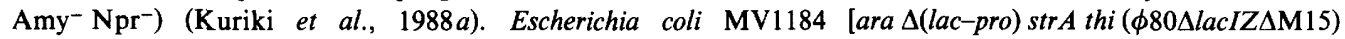

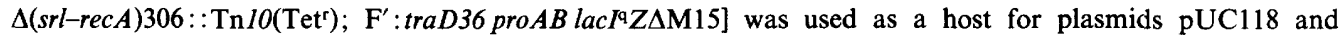


pUC119 and for phage M13KO7 (Vieira \& Messing, 1987). Plasmid pPP10 [Tcr $n p l T^{+}$(structural gene of the neopullulanase from B. stearothermophilus TRS40)] was described previously (Kuriki et al., 1988a).

Plasmid isolation, restriction enzyme treatment, and ligation of DNA. Plasmid DNA was prepared by either the rapid alkaline extraction method or $\mathrm{CsCl} /$ ethidium bromide equilibrium density gradient centrifugation as described previously (Imanaka et al., 1982). Treatment of DNA with restriction enzymes and ligation of DNA with T4 DNA ligase were done as recommended by the manufacturer.

Transformation. Transformation of $E$. coli with plasmid DNA, and transformation of competent $B$. subtilis cells, were done as described previously (Imanaka et al., 1981).

Gel electrophoresis for DNA analysis and isolation. For the analysis of DNA, gel electrophoresis with agarose or polyacrylamide was done under standard conditions (Maniatis et al., 1982). A GENECLEAN kit (BIO 101, La Jolla, Calif., USA) was used for the recovery of DNA from agarose.

DNA sequencing analysis. DNA sequencing was done by the dideoxy chain-terminating method (Sanger et al., 1977) with a SEQUENASE kit (United State Biochemical Corporation, Cleveland, Oh., USA). For preparing singlestranded DNA, pUC118/119 and helper phage M13KO7 were used (Vieira \& Messing, 1987). Some strands were analysed by the dideoxy sequencing method using alkaline denatured plasmid templates (Hattori \& Sakaki, 1986). Although some parts of the DNA were analysed from one strand, those sequences could be determined without any ambiguity on the sequencing gels, because the substitution of dGTP by the nucleotide analogue dITP with the SEQUENASE kit was successful in elimination of compressed regions. All restriction sites were overlapped by sequencing across them.

Detection of neopullulanase-producing colonies and assay of neopullulanase activity. Neopullulanase-producing colonies were selected on PLL agar plates and neopullulanase activity was assayed at $50^{\circ} \mathrm{C}$ as described previously (Kuriki et al., 1988a).

Purification of neopullulanase. B. subtilis NA-1(pPP10) was cultivated in LSII broth (Kuriki et al., 1988a) at $37^{\circ} \mathrm{C}$ for $16 \mathrm{~h}$. The culture supernatant was used for enzyme purification. Purification procedures for the neopullulanase were described previously (Kuriki et al., 1988a).

Amino acid composition and amino-terminal amino acid sequence. Using neopullulanase purified to homogeneity, the amino acid composition was analysed as described previously (Matsumura et al., 1984). The amino-terminal amino acid sequence was analysed by Edman degradation as described elsewhere (Takagi et al., 1985).

Enzymes and chemicals. Restriction endonucleases, T4 DNA ligase, and DNA polymerase I (Klenow fragment) were purchased from Takara Shuzo Co., Kyoto, Japan. Tetracycline was from Sigma. All other chemicals used were from Wako Pure Chemical Industries, Osaka, Japan.

Analysis of amino acid sequence homology. This was done with an NEC PC-9801 computer (Nippon Electric Co.) and the GENETYX system (Software Development Co., Tokyo, Japan).

\section{RESULTS}

\section{Nucleotide sequence of the neopullulanase gene}

We have previously shown that the structural gene for the neopullulanase (nplT) from $B$. stearothermophilus TRS40 is cloned in a $3.4 \mathrm{~kb}(2.2 \mathrm{MDa})$ HindIII fragment of plasmid pPP10 (Kuriki et al., 1988a). Fig. 1 shows the restriction map of the $3.4 \mathrm{~kb}$ HindIII fragment. Using a frame-shift mutation generated by end-filling with DNA polymerase I, we confirmed that a single $S a l$ I site was located in $n p l T$. The nucleotide sequence of $n p l T$ was determined (Fig. 2), according to the strategy shown in Fig. 1.

To correlate the nucleotide sequence data with the structure of the neopullulanase, the aminoterminal amino acid sequence of the enzyme from B. subtilis NA-1(pPP10) was determined through five cycles of the Edman degradation procedure (Allen, 1981). The first five amino acids of the enzyme were Met-Arg-Lys-Glu-Ala. This sequence completely matched that deduced from the nucleotide sequence only when ATG was taken as the initiation codon at position +1 (Fig. 2).

Starting from the ATG codon at position +1 and terminating in a TAG nonsense codon at position +1765 , the single open reading frame was composed of 1764 nucleotides (Fig. 2). The maximum length of other open reading frames was 474 nucleotides in the two other reading frames of the same strand and the three reading frames of the complementary strand.

At 6 bases upstream from the ATG codon, there was a 10-base sequence, AAGGAGGAGA $(-16$ to -7$)$, which exhibited complementarity with the $3^{\prime}$ end of the 16S rRNA from $B$. stearothermophilus (Kozak, 1983) and B. subtilis (Moran et al., 1982); hence it is the most probable ribosome-binding site (Shine-Dalgarno sequence) of $n p l T$. The free energy of 


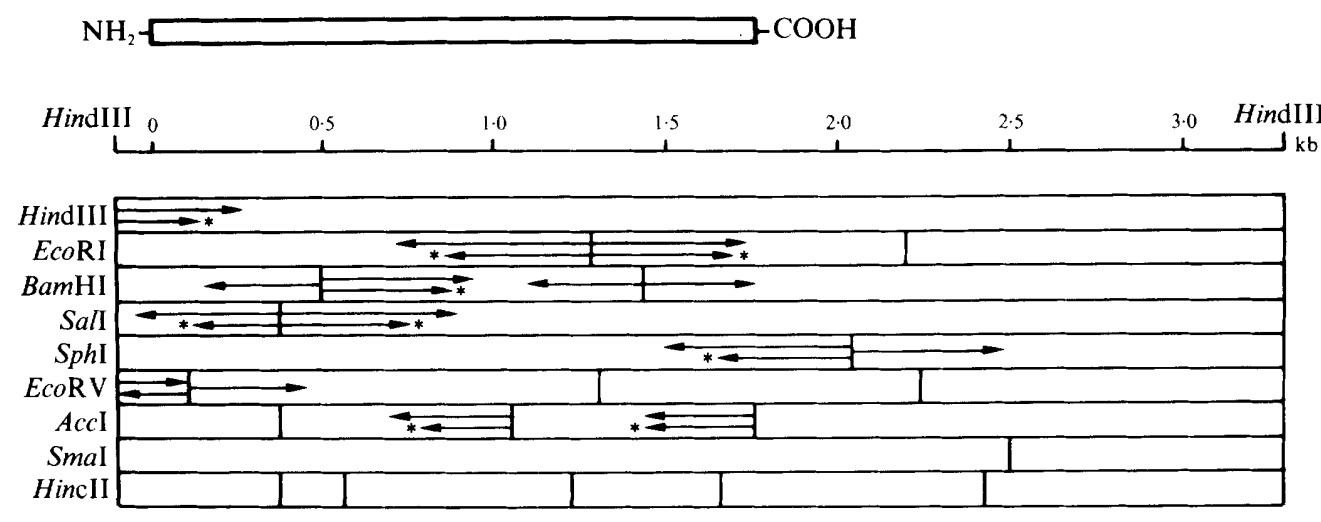

Fig. 1. Restriction map and sequencing strategy of the $3.4 \mathrm{~kb}$ HindIII fragment of pPP10. The location and size of the neopullulanase gene are shown by the open bar. Arrows indicate the direction and length of individual sequence determinations. Asterisks indicate the regions analysed using dITP.

formation of the most stable pairing was calculated as $-18 \cdot 0 \mathrm{kcal} \mathrm{mol}^{-1}\left(-75 \cdot 3 \mathrm{~kJ} \mathrm{~mol}^{-1}\right)$ (Tinoco et al., 1973).

Two putative promoters ( -35 and -10 regions) are shown in Fig. 2 ; one is TTGACTTTTTTTCTCTCTTTTCGTACTCT $(-90$ to -62$)$ and the other TTTTTTTCTCTCTTTTCGTACTCTTTAAT $(-85$ to -57$)$. However, these two putative promoters are somewhat different from the consensus sequence for the $\sigma^{43}$ factor (TTGACA for the -35 region and TATAAT for the -10 region) in $B$. subtilis (Moran et al., 1982). The distance between the -35 region and the -10 region was $17 \mathrm{bp}$ for each promoter, which is the same as the consensus distance in B. subtilis (Moran et al., 1982). Furthermore, 39 bases downstream from the termination codon at position +1765 was a palindromic sequence (Fig. 2) that might act as a transcription terminator (Rosenberg \& Court, 1979).

\section{Amino acid analysis}

The $M_{\mathrm{r}}$ of the neopullulanase, calculated as 69144 from the amino acid sequence (588 amino acid residues), is in reasonable agreement with the direct assessment $\left(M_{\mathrm{r}} 62000\right)$ by SDS polyacrylamide gel electrophoresis (Kuriki et al., 1988a). The amino acid composition of the neopullulanase agreed with that deduced from the nucleotide sequence (data not shown). The codon usage was rather randomly distributed, without clear bias for any particular thirdposition base, and was nearly the same as that of $B$. stearothermophilus $\alpha$-amylase (Nakajima $e t$ al., 1985).

The neopullulanase contained eight cysteine residues (Fig. 2). If some disulphide bonds existed, they might provide conformational stability (Perry \& Wetzel, 1984). To examine whether disulphide bonds were present in the neopullulanase, we compared the thermostability of the enzyme in the presence or absence of a reducing agent. 2-Mercaptoethanol (final concentration $10 \mathrm{~mm}$ ) was added to the enzyme solution and the thermostability at 60,65 and $70{ }^{\circ} \mathrm{C}$ was measured as described previously (Kuriki et al., 1988a). The thermostability and specific activity of the reduced neopullulanase were rather higher than those of the native (nonreduced) enzyme, although the reason is not clear yet (data not shown). This result implied that the neopullulanase did not contain any disulphide bonds necessary for enzyme activity or for stability.

Comparison of the amino acid sequences of homologous regions in several amylolytic enzymes

We analysed the homologous amino acid sequences for $\alpha$-amylases (Nakajima et al., 1986), the neopullulanase, isoamylase (Amemura et al., 1988), pullulanase (Katsuragi et al., 1987) and cyclodextrin glucanotransferases (Binder et al., 1986; Kimura et al., 1987; Sakai et al., 1987). As 
$-100$

AAGCTTTTTTCTACTGAAT
-35 region
$-10 \overline{\text { region }}$

$+1$

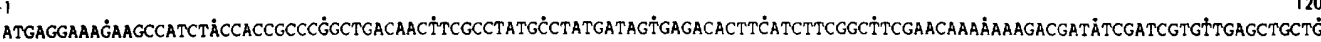


1

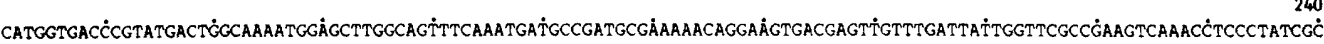
HisGlyAspProTyrAspTrpGlnAsnGlyAlaTrpGInPheGlnMetMetProMetArgLysThrGlySerAspGluLedPheAspTyrTrpPheAlaGluValLysProProTyrArg 60

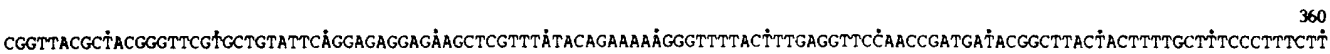
ArgLeuArgTyrGlyPheValLeuTyrSerGl yGluGluLysLeuValTyrThrGluLysGlyPheTyrPheGluValProThrAspAspThrAlaTyrTyrPheCysPheProPheLeu 100

CATCGAGTCǴACTTGTTCG HisArgValAspLeuPheGluA laProAspTrpValLysAspThrValTrpTyrGlnIl ePheProGluArgPheAlaAsnGlyAsnProSerI leSerProGluGlySerArgProTrp 140


GlySerGluAspProThrProThrSerPhePheGlyGlyAspLeuGlnGly I leI leAspH isLeLAspTyrLeuValAspLeuGl y I leThrGly I leTyrLeuThrProI lePheArg 180

720

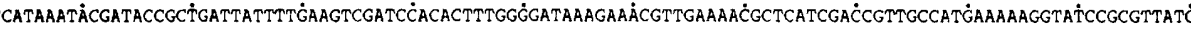
SerProSerAsnHisLysTyrAspThrAlaAspTyrPheGliValAspProHisPheGlyAspLysGluThrLeuLysThrLeuI leAspArgCysHisGluLysGlyI leArgValMet 220

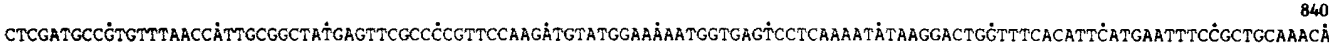
LeuAspAlaValPheAsr.HisCysGl yTyrGl IPheAl aProPheGlnAspValTrpLysAsnGiyGluSerSerLysTyrLysAspTrpPheH is I leHisGl uPheProLeuGlnThr 260

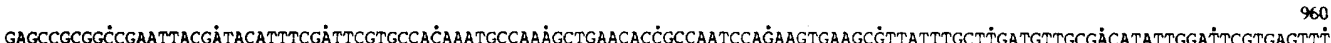
GluProArgProAsnTyrAspThrPheArgPheValProGInMetProLysLeuAsnThrAlaAsnProGluVallysArgTyrLeuLeuAspValAlaThrTyrTrpIleArgGluPhe

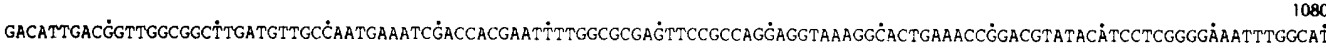

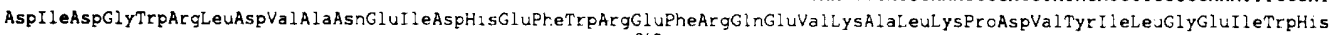
340

1200

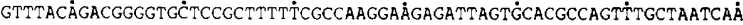

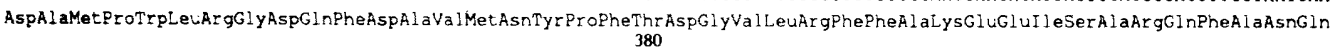

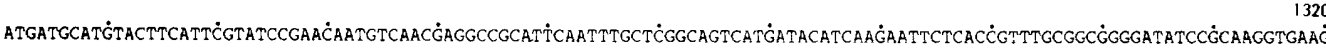

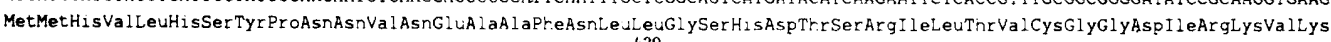
420

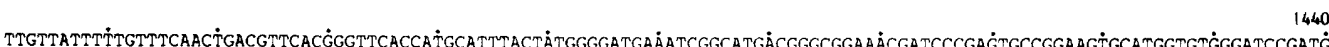
LeuLeuPheLeuPheGlr.LeuThrPheThrGlySerProCys I leTyrTyrGlyAspGluIl eGlyMetThrGlyGlyAs?AspProGl LCysArgLysCysMetValTrpAspProMet

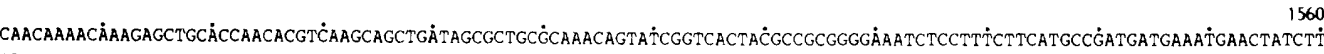


500

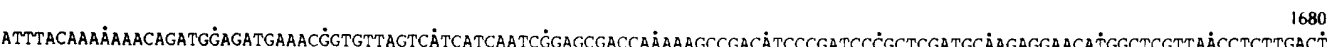
IleTyrLysLysThrAspGlyAspGl UThrValLeuVal I leI LeAsnArgSerAspGInLysAi aAsp I leProI leProLeuAspAlaArgGlyTh.rTrpLeuValAsnLeuLeuThr 540

1800

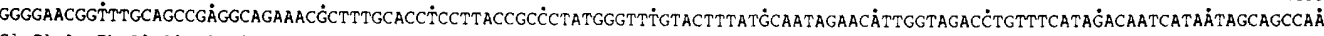
GlYGIUArgPheAlaAlaGI UAlaGluThrLeuCysThrSerLeuProProTyrGl YPheValLeLTyrAlaI leGluHis Trp***

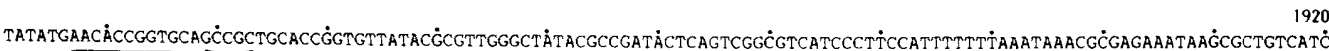

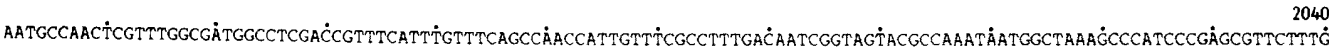




\begin{tabular}{|c|c|c|c|c|c|}
\hline AN & $\mathrm{Co}$ & $\begin{array}{l}\text { Region } 1 \\
\text { D A V I N } \mathbf{~}\end{array}$ & $\begin{array}{c}\text { Region } 2 \\
\text { G F R L D A A K H }\end{array}$ & $\begin{array}{l}\text { Region } 3 \\
\text { E V I D }\end{array}$ & $\begin{array}{l}\text { Region } 4 \\
\text { F V D N H D }\end{array}$ \\
\hline M & A. $C$ & 117 \& V Y A & 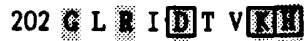 & $230 @ \mathrm{OLD}$ & 292 F V E N⿴囗十D \\
\hline M & & F D U & UD, V K & $2648 Y$ Y S & N 110 \\
\hline & $B$. & 4 & 227 & 261 Y Y Q & $323 \mathrm{~F}$ \\
\hline 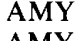 & B. $s$ & W & 172 & $208 \mathrm{~V} I \mathrm{LQ}$ & $264 W$ \\
\hline 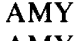 & Rat & & 190 & 230 \& $1 \mathrm{D}$ & $292 \mathrm{~F}$ \\
\hline M) & Mc & H & 15 & $233 \mathrm{DV} / \mathrm{D}$ & 295 \\
\hline I & Mc & $\mathrm{H}$ & 190 & $230 \mathrm{~V} V 1 \mathrm{D}$ & $292 \mathrm{~F}$ \\
\hline$Y$ & Hog & I 11 & 193 & $233 \mathrm{~B} \cup 1 \mathrm{D}$ & $295 \mathrm{~F} \mathrm{~V}$ \\
\hline MY & $1, s$ & 99 & 196 & 236 BVI D & $298 \mathrm{~F}$ \\
\hline MY & , p & B A Y I I & $196 \%$ & $236 \mathrm{BV}$ Y D & 298 F V \\
\hline AMY & Bar & $2 \mathrm{I} / 4 \mathrm{I}$ & 127 D G R L D W $P$ A & 218 B V W D & 299 E V \\
\hline NPL & tro. & 242 D UV F I T & 324 GW R L D & 357 E I W H & 419 L L \\
\hline $\mathbf{M}$ & lo. & V. & 370 & 454 B W V V & 502 \\
\hline UL & C. & $600 \mathrm{D}$ & 6716 & 704 E G W D & 827 Y V \\
\hline CGT & K. $p$ & 130 DY A D \& I & RIBAI SH & 257 E W F G & $328 \mathrm{~F}$ \\
\hline GT & $m$ & & 225 & 258 & 324 \\
\hline & & & 225 & $268 \mathrm{~B} Y \mathrm{H} \mathrm{Q}$ & 323 \\
\hline GT & aro. & & & 253 & $\pi$ \\
\hline
\end{tabular}

Fig. 3. Highly conserved regions among $\alpha$-amylase, neopullulanase, isoamylase, pullulanase and cyclodextrin glucanotransferase. The amino acid residues identical with the consensus sequence of $\alpha$ amylase are shaded. Amino acid residues are shown by single letters as follows: A, Ala; D, Asp; E, Glu; F, Phe; G, Gly; H, His; I, Ile; K, Lys; L, Leu; M, Met; N, Asn; P, Pro; Q, Gln; R, Arg; S, Ser; T, Thr; V, Val; W, Trp; Y, Tyr. Enzymes are abbreviated as: AMY, $\alpha$-amylase; NPL, neopullulanase; IAM, isoamylase; PUL, pullulanase; CGT, cyclodextrin glucanotransferase. Enzyme sources are abbreviated as: A. ory., Aspergillus oryzae; B. stearo., Bacillus stearothermophilus; B. amylo., Bacillus amyloliquefaciens; B. sub., Bacillus subtilis; P. amylo., Pseudomonas amyloderamosa; K. aero., Klebsiella aerogenes; K. pne., Klebsiella pneumoniae; B. mace., Bacillus macerans; Alk. B., alkalophilic Bacillus; s, saliva; p, pancreas. For the reference of each amino acid sequence, see the text. Numbering of the amino acid sequences of the enzymes starts at the amino-terminal amino acid of each mature enzyme. Active sites and substrate binding sites proposed by Matsuura et al. (1984) for Taka-amylase A from $A$. oryzae are indicated by $\bigcirc$ and $\square$, respectively.

the results demonstrate (Fig. 3), the four highly conserved regions previously demonstrated in $\alpha$-amylases were also found in the neopullulanase, isoamylase, pullulanase and cyclodextrin glucanotransferases. The arrangement of regions 1, 2, 3 and 4 from the amino-termini among these enzymes were the same. The other parts of the neopullulanase showed almost no similarity to those of $\alpha$-amylases, isoamylase, pullulanase and cyclodextrin glucanotransferases.

\section{DISCUSSION}

We have determined the complete nucleotide sequence of the gene for a new type of pullulanhydrolysing enzyme, designated neopullulanase, from B. stearothermophilus TRS40. An open reading frame, composed of 1764 bases and 588 amino acid residues, was found. The thermostable neopullulanase contained eight cysteine residues. However, they did not provide conformational stability through disulphide bond formation.

Fig. 2. Nucleotide and amino acid sequences of the neopullulanase gene. The nucleotide sequence is presented from the HindIII site (nucleotide -109 ) to the $S p h$ I site (nucleotide +2045 ). The nucleotide sequence is counted from the first base of open reading frame. The amino acid sequence is shown beneath the nucleotide sequence. The amino-terminal amino acid sequence of the neopullulanase, determined by the Edman method, is denoted by half-head arrows. The first amino acid of the translation (Met) is counted as 1 . A probable Shine-Dalgarno sequence (nucleotide -16 to -7 ) and putative promoter regions ( -35 and -10 regions) are shown by solid lines below the nucleotide sequence. Asterisks indicate a stop codon. The sequence containing inverted repeat structures downstream from the termination codon TAG is designated by $\rightarrow \leftarrow$. 


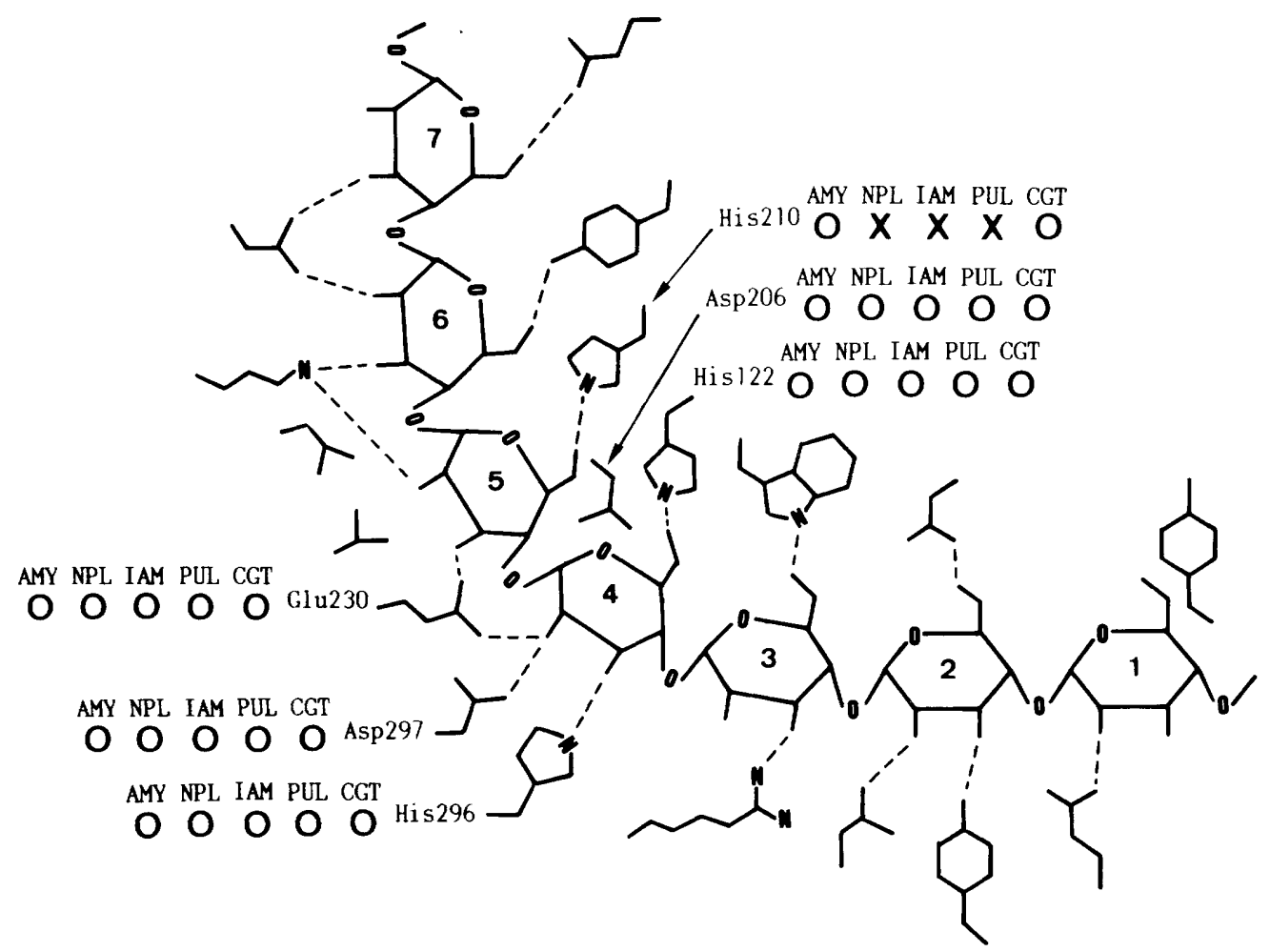

Fig. 4. Proposed substrate-binding model of Taka-amylase A (Matsuura et al., 1984) and conservation of corresponding amino acid residues in other $\alpha$-amylases, neopullulanase, isoamylase, pullulanase and cyclodextrin glucanotransferases (see Fig. 3). The glucose residues of amylose (as a substrate) are specified by the numbers 1 to 7. Enzymes are abbreviated as in Fig. 3. O, Conserved residue; $x$, nonconserved residue.

Table 1. Action of various amylolytic enzymes

Relative hydrolysis and transglucosylation rates are indicated as follows: ++ , strong; + , medium; \pm , weak; - , none. $\alpha-(1 \rightarrow 4), \alpha-(1 \rightarrow 4)$-glucosidic linkage; $\alpha-(1 \rightarrow 6), \alpha-(1 \rightarrow 6)$-glucosidic linkage.

Enzyme

$\alpha$-Amylase

Neopullulanase

Isoamylase

Pullulanase

Cyclodextrin

glucanotransferase
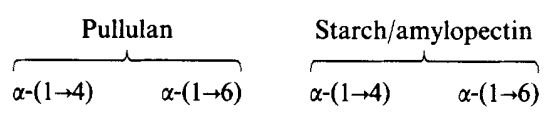

$\begin{array}{cc}- & - \\ ++ & + \\ - & - \\ - & ++\end{array}$

$++$

$\pm$

$-$

$++$

$$
\overbrace{\alpha-(1 \rightarrow 4)}^{\text {Glycogen }} \underbrace{}_{\alpha-(1 \rightarrow 6)}
$$$$
\begin{aligned}
& - \\
& \pm \\
& ++ \\
& ++ \\
& -
\end{aligned}
$$

Transglucosylation

$$
\pm
$$$$
++
$$$$
\pm
$$

Although most of the amylolytic enzymes are secretory proteins, no typical signal sequence was found in the amino-terminal region of the neopullulanase. When B. subtilis NA-1(pPP10) was cultivated for $13 \mathrm{~h}$ (early stationary phase), about $20 \%$ of the total neopullulanase activity was detected in the culture supernatant. Since a major portion of the activity (about $80 \%$ ) was found in the cell extract, which was prepared by sonication $(19.5 \mathrm{KHz}, 10 \mathrm{~min})$, we purified the intracellular neopullulanase, and the amino-terminal amino acid sequence was compared with that of the enzyme purified from the culture supernatant. The sequences of the first five amino 
acids of the enzymes from the two different preparations were identical. Since the neopullulanase was exclusively extracellular in B. stearothermophilus TRS40, the different localization of the neopullulanase in $B$. subtilis remains to be investigated.

We found four highly conserved regions in $\alpha$-amylase, cyclodextrin glucanotransferase, and even in the neopullulanase, isoamylase and pullulanase, whose different patterns of action are summarized in Table 1 . This finding might be very interesting to point out the homologies between $\alpha-(1 \rightarrow 4)$-glucanohydrolases ( $\alpha$-amylase and cyclodextrin glucanotransferase) and $\alpha$ $(1 \rightarrow 6)$-glucanohydrolases (isoamylase and pullulanase). Pullulanase hydrolyses pullulan, whereas isoamylase does not. The neopullulanase hydrolyses not only $\alpha$-(1 $1 \rightarrow 4)$-but also $\alpha-(1 \rightarrow 6)$-glucosidic linkages (Imanaka \& Kuriki, 1989; Kuriki et al., 1988a). The enzyme could hydrolyse pullulan efficiently and only a small amount of starch (Kuriki et al., 1988a). Therefore, the neopullulanase is a novel enzyme which might be classified between $\alpha$-amylase and pullulanase from the viewpoint of its action pattern.

In this context, we analysed the homologies of other glucanohydrolases, such as glucoamylase (EC 3.2.1.3) (Yamashita et al., 1985), $\beta$-amylase (EC 3.2.1.2) (Rhodes et al., 1987), cellulase (EC 3.2.1.4) (Béguin et al., 1985; Fukumori et al., 1986), maltase ( $\alpha$-D-glucosidase; EC 3.2.1.20) (Hong \& Marmur, 1986) and isomaltase (oligo-1,6-glucosidase; EC 3.2.1.10) (Hunziker et al., 1986). However, no significant homologies were found (data not shown).

A molecular model and catalytic residues of Taka-amylase A from Aspergillus oryzae were reported by Matsuura et al. (1984). Using the alignment of amino acid residues in homologous regions (Fig. 3), this model was applied for other $\alpha$-amylases, the neopullulanase, isoamylase, pullulanase and cyclodextrin glucanotransferases (Fig. 4). Glu230 and Asp297 were proposed as active sites of Taka-amylase, and His122, Asp206, His210 and His296 were proposed as substrate-binding sites (Matsuura et al., 1984). These active and substrate-binding sites were surprisingly conserved in other $\alpha$-amylases, the neopullulanase isoamylase, pullulanase and cyclodextrin glucanotransferases (Figs 3 and 4). However, one substrate-binding-site residue, corresponding to His 210 of Taka-amylase, was substituted by Glu, Val or Tyr in the neopullulanase, isoamylase or pullulanase, respectively. It is interesting that only these three enzymes can hydrolyse $\alpha-(1 \rightarrow 6)$-glucosidic linkages (Table 1$)$.

Plant et al. (1987) suggested the presence of a carboxyl group with $\mathrm{p} \mathrm{Ka} 4.3$ at the active site of Thermoanaerobium pullulanase. It was considered most likely that the $\mathrm{p} K a$ value of 4.3 represented the ionization of a Glu or Asp carboxyl group, and this view was confirmed by chemical modification with a carboxyl-group-specific reagent, 1-(3-dimethylaminopropyl)-3ethylcarbodi-imide (Plant et al., 1987). This finding is consistent with the hypothesis that Glu and/or Asp might be active-site residues in all the amylolytic enzymes shown in Figs 3 and 4.

To further investigate the role of the amino acid residues for catalytic activity and action pattern of the neopullulanase, and also to improve the characterization of the enzyme at the molecular level, amino acid substitution in the probable active site by site-directed mutagenesis is now in progress.

\section{REFERENCES}

Allen, G. (1981). Sequencing of proteins and peptides. In Laboratory Technique in Biochemistry and Molecular Biology, pp. 161-236. Edited by T. S. Work \& R. H. Burdon. Amsterdam: North-Holland Publishing Co.

Amemura, A., Chakraborty, R., Fujita, M., Noumi, T. \& FUTAI, M. (1988). Cloning and nucleotide sequence of the isoamylase gene from Pseudomonas amyloderamosa SB-15. Journal of Biological Chemistry 263, 9271-9275.

Béguin, P., Cornet, P., \& Aubert, J.-P. (1985). Sequence of a cellulase gene of the thermophilic bacterium Clostridium thermocellum. Journal of Bacteriology 162, 102-105.

Binder, F., Huber, O. \& Böck, A. (1986). Cyclodex- trin-glycosyltransferase from Klebsiella pneumoniae M5a1 : cloning, nucleotide sequence and expression. Gene 47, 269-277.

Fukumori, F., Sashihara, N., Kudo, T. \& Horikoshi, K. (1986). Nucleotide sequences of two cellulase genes from alkalophilic Bacillus sp. strain N-4 and their strong homology. Journal of Bacteriology 168, 479-485.

HATTORI, M. \& SAKAKI, Y. (1986). Dideoxy sequencing method using denatured plasmid templates. Analytical Biochemistry 152, 232-238.

Hong, S. H. \& Marmur, J. (1986). Primary structure of the maltase gene of the MAL6 locus of Saccharomyces carlsbergensis. Gene 41, 75-84.

Hunziker, W., SpIess, M., Semenza, G. \& Lodish, 
H. F. (1986). The sucrase-isomaltase complex: primary structure, membrane-orientation, and evolution of a stalked, intrinsic brush border protein. Cell 46, 227-234.

IMANAKA, T. \& KURIKI, T. (1989). Pattern of action of Bacillus stearothermophilus neopullanase on pullulan. Journal of Bacteriology 171, 369-374.

Imanaka, T., Tanaka, T., Tsunekawa, H. \& Aiba, S. (1981). Cloning of the genes for penicillinase, penP and penI, of Bacillus licheniformis in some vector plasmids and their expression in Escherichia coli, Bacillus subtilis, and Bacillus licheniformis. Journal of Bacteriology 147, 776-786.

ImanaKa, T., Fujil, M., Aramori, I. \& Aiba, S. (1982). Transformation of Bacillus stearothermophilus with plasmid DNA and characterization of shuttle vector plasmids between Bacillus stearothermophilus and Bacillus subtilis. Journal of Bacteriology 149, 824-830.

Katsuragi, N., Takizawa, N. \& Murooka, Y. (1987). Entire nucleotide sequence of the pullulanase gene of Klebsiella aerogenes W70. Journal of Bacteriology 169, 2301-2306.

KimURA, K., KaTAOKa, S., Ishil, Y., Takano, T. \& YAMANE, K. (1987). Nucleotide sequence of the $\beta$ cyclodextrin glucanotransferase gene of alkalophilic Bacillus sp. strain 1011 and similarity of its amino acid sequence to those of $\alpha$-amylases. Journal of Bacteriology 169, 4399-4402.

KozAK, M. (1983). Comparison of initiation of protein synthesis in procaryotes, eucaryotes, and organelles. Microbiological Reviews 47, 1-45.

Kuriki, T., OKaDA, S. \& Imanaka, T. (1988a). New type of pullulanase from Bacillus stearothermophilus and molecular cloning and expression of the gene in Bacillus subtilis. Journal of Bacteriology 170, 15541559.

Kuriki, T., Park, J.-H., Okada, S. \& Imanaka, T. $(1988 b)$. Purification and characterization of thermostable pullulanase from Bacillus stearothermophilus and molecular cloning and expression of the gene in Bacillus subtilis. Applied and Environmental Microbiology 54, 2881-2883.

Maniatis, T., Fritsch, E. F. \& SAMbroox, J. (editors) (1982). Gel electrophoresis. In Molecular Cloning : $a$ Laboratory Manual, pp. 149-185. Cold Spring Harbor, NY: Cold Spring Harbor Laboratory.

Matsumura, M., Katakura, Y., ImanaKa, T. \& Aiba, S. (1984). Enzymatic and nucleotide sequence studies of a kanamycin-inactivating enzyme encoded by a plasmid from thermophilic bacilli in comparison with that encoded by plasmid pUB110. Journal of Bacteriology 160, 413-420.

MatsuUra, Y., Kusunoki, M., Harada, W. \& KAKUDO, M. (1984). Structure and possible catalytic residues of Taka-amylase A. Journal of Biochemistry 95, 697-702.

McPherson, M. J. \& Charalambous, B. M. (1988).
Functional analysis of the starch debranching enzyme pullulanase. Biochemical Society Transactions 16, 723-724.

Moran, C. P., JR, LANG, N., LeGrice, S. F. J., LeE, G., Stephens, M., Sonenshein, A. L., Pero, J. \& Losick, R. (1982). Nucleotide sequences that signal the initiation of transcription and translation in Bacillus subtilis. Molecular and General Genetics 186, 339-346.

NAKajImA, R., ImanaKA, T. \& AIBA, S. (1985). Nucleotide sequence of the Bacillus stearothermophilus $\alpha$-amylase gene. Journal of Bacteriology 163, 401406.

NAKAJIMA, R., IMANAKA, T. \& AIBA, S. (1986). Comparison of amino acid sequences of eleven different $\alpha$-amylases. Applied Microbiology and Biotechnology 23, 355-360.

Perry, L. J. \& Wetzel, R. (1984). Disulfide bond engineered into $\mathrm{T} 4$ lysozyme: stabilization of the protein toward thermal inactivation. Science 226, 555-557.

Plant, A. R., Clemens, R. M., Morgan, H. W. \& DANIEL, R. M. (1987). Active-site and substratespecificity of Thermoanaerobium Tok6-B1 pullulanase. Biochemical Journal 246, 537-541.

Rhodes, C., Strasser, J. \& Friedberg, F. (1987). Sequence of an active fragment of $B$. polymyxa beta amylase. Nucleic Acids Research 15, 3934.

ROSENBERG, M. \& COURT, D. (1979). Regulatory sequences involved in the promotion and termination of RNA transcription. Annual Review of Genetics 13, 319-353.

Sakai, S., Kubota, M., Yamamoto, K., Nakada, T., TORIGOE, K., ANDO, O. \& Sugimoto, T. (1987). Cloning of cyclodextrin glucanotransferase genes from B. stearothermophilus and B. macerans. Journal of the Japanese Society of Starch Science 34, 140-147.

Sanger, F., Nicklen, S. \& Coulson, A. R. (1977). DNA sequencing with chain-terminating inhibitors. Proceedings of the National Academy of Sciences of the United States of America 74, 5463-5467.

TakaGi, M., Imanaka, T. \& AIBA, S. (1985). Nucleotide sequence and promoter region for the neutral protease gene from Bacillus stearothermophilus. Journal of Bacteriology 163, 824-831.

Tinoco, I., JR, Borer, P. N., Dengler, B., Levine, M. D., Uhlenbeck, O. C., Crothers, D. M. \& Gralla, J. (1973). Improved estimation of secondary structure in ribonucleic acids. Nature New Biology 246, 40-41.

Vieira, J. \& Messing, J. (1987). Production of singlestranded plasmid DNA. Methods in Enzymology 153, 3-11.

Yamashita, I., Suzuki, K. \& Fukui, S. (1985). Nucleotide sequence of the extracellular glucoamylase gene $S T A 1$ in the yeast Saccharomyces diastaticus. Journal of Bacteriology 161, 567-573. 